University of Nebraska - Lincoln

DigitalCommons@University of Nebraska - Lincoln

Publications from USDA-ARS / UNL Faculty

U.S. Department of Agriculture: Agricultural

Research Service, Lincoln, Nebraska

2004

Pest management benefits of compost mulch in apple orchards

M. W. Brown

USDA

Thomas Tworkoski

USDA

Follow this and additional works at: https://digitalcommons.unl.edu/usdaarsfacpub

Part of the Agricultural Science Commons

Brown, M. W. and Tworkoski, Thomas, "Pest management benefits of compost mulch in apple orchards" (2004). Publications from USDA-ARS / UNL Faculty. 342.

https://digitalcommons.unl.edu/usdaarsfacpub/342

This Article is brought to you for free and open access by the U.S. Department of Agriculture: Agricultural Research Service, Lincoln, Nebraska at DigitalCommons@University of Nebraska - Lincoln. It has been accepted for inclusion in Publications from USDA-ARS / UNL Faculty by an authorized administrator of DigitalCommons@University of Nebraska - Lincoln. 


\title{
Pest management benefits of compost mulch in apple orchards
}

\author{
M.W. Brown*, Thomas Tworkoski \\ USDA, Agricultural Research Service, Appalachian Fruit Research Station, 2217 Wiltshire Road, Kearneysville, WV 25430, USA
}

Received 10 March 2003; received in revised form 18 November 2003; accepted 27 November 2003

\begin{abstract}
The effect of compost application on weed, fungal, and insect pest management in apple orchards was investigated from 1999 to 2001. Composted poultry manure was applied in June 1999 to half of two small research orchards which had previously received little or no management. The compost provided weed control for 1 year after application. There was no effect of compost on apple scab (Venturia inaequalis) infection. In a laboratory experiment, growth of the brown rot fungus (Monilinia fructicola) was significantly slower on a compost substrate than a sterilized compost substrate. The compost significantly affected arthropod abundance during two years after application, with more predators and fewer herbivores in the compost treated plots. Populations of spotted tentiform leafminer (Phyllonorycter blancardella) and migrating woolly apple aphid (Eriosoma lanigerum) nymphs were reduced in the compost plots. This study showed that the use of compost in an orchard ecosystem is beneficial to management of weed, fungal, and insect pests. The use of compost as a mulch in orchard ecosystems should be encouraged as a sustainable management practice because of a potential to reduce pesticide use.

Published by Elsevier B.V.
\end{abstract}

Keywords: Apple; Compost; Sustainable agriculture; Weed management; Fruit disease management; Insect pest management; North America

\section{Introduction}

The benefits of organic compost additions to soil structure and nutritional dynamics are well documented (Allison, 1973; Glover et al., 2000; Andrews et al., 2001). Adding organic compost to apple orchards has been shown to increase bloom and growth of newly planted trees (Autio et al., 1991) and fruit yields (Niggli et al., 1990). Compost increases soil biodiversity, which is essential to maintaining soil health (Kennedy, 1999). Soil health has been suggested to be used as a primary indicator of sustainable management (Doran, 2002). The use of compost as part of an organic approach to apple production has

\footnotetext{
* Corresponding author. Tel.: +1-304-725-3451; fax: +1-304-728-2340.

E-mail address: mbrown@afrs.ars.usda.gov (M.W. Brown).
}

been shown to be cost effective when compared with conventional practices (Reganold et al., 2001). A variety of organic materials have been used as mulch to suppress weeds and improve soil fertility (Cogliastro et al., 1993; Pinamonti, 1998; Arthur and Wang, 1999; Lu et al., 1999). Weeds were successfully controlled with organic mulches in California, which included woodchip waste in young pecan trees and composted poultry manure in an organic apple orchard (Swezey et al., 1998; Smith et al., 2000).

Numerous studies have shown that compost can reduce soil-borne diseases in a variety of cropping systems (Windels, 1997; Hoitink and Boehm, 1999). Organic amendments to the soil are reported to enhance various fungi, mites, collembola (Morris, 1922; Pimentel and Warneke, 1989; Badejo et al., 1995), and predatory arthropods such as spiders and carabid beetles (Morris, 1922; Reichert and Bishop, 1990; 
Mathews et al., 2002). Studies exploring the impact of compost on arthropods have largely dealt with effects on the abundance and diversity of the soil-dwelling arthropod community. Some studies have also shown a reduction in pest incidence associated with increased predator abundance in crops treated with organic mulches (Culliney and Pimentel, 1985; Reichert and Bishop, 1990; Brust, 1993). Mathews et al. (2002) showed that the increase in arthropod predators in a young apple orchard was related to the organic properties of the material added to the soil ecosystem rather than the physical properties. Settle et al. (1996) found that adding organic matter to the rice (Oryza sativa L.) ecosystem not only increased detritivore and predator abundance but also enhanced the sustainability of rice production.

In the current study, a similar "bottom-up" approach was investigated to enhance system-wide biological control. The detritivore trophic level was provided additional food resources by adding compost mulch. The resulting effects were examined on various trophic levels: weeds, fungal pathogens, and insect pests; concentrating on specific pests, as indicators of system-wide effects. The effects of compost on abundance of weeds, apple scab (Venturia inaequalis (Cooke) G. Wint.), growth of the brown rot fungus (Monilinia fructicola (G. Wint) Honey), and two arthropod pests, woolly apple aphid (Eriosoma lanigerum Hausman) (Homoptera: Aphididae) and spotted tentiform leafminer (Phyllonorycter blancardella (F.)) (Lepidoptera: Gracillariidae), were directly evaluated.

\section{Materials and methods}

Two small (0.15 ha), 16-year-old apple (Malus domestica Borkh.) orchards at the Appalachian Fruit Research Station, Kearneysville, WV, were used for field experiments. Each orchard had five rows of trees planted at $4 \mathrm{~m} \times 5 \mathrm{~m}$ spacing with one orchard having 18 trees per row and the other from 8 to 21 trees per row. Both orchards were adjacent to wild habitat and within $50 \mathrm{~m}$ of an unmanaged apple orchard. Orchards were planted in April 1984, with equal numbers of the cultivars 'Delicious', 'Golden Delicious', 'York Imperial', 'Stayman Winesap', and 'Empire' on the semi-dwarfing rootstock, M.7A. The soil in the orchards was Hagerstown silt loam (fine, mixed, mesic
Typic Hapludalf). Prior to plot establishment the orchards received minimal management with pruning every 2 years, mowing 2 or 3 times per year, and the herbicide $1,1^{\prime}$-dimethyl-4,4'-bipyridinium (paraquat) applied under the trees every 2 years. The orchards received no fertilizer or fungicide, and fruit was allowed to drop under the trees. No insecticide had been used in either orchard for 10 years.

In May 1999, glyphosate ( $N$-(phosphonomethyl) glycine) was applied as a spot treatment on all weeds that had emerged in a $3 \mathrm{~m}$ wide strip under all the trees in both orchards. In each orchard, 20 treatment plots comprising four consecutive trees within a row were established. Ten plots in each orchard were randomly selected to receive a pre-emergent herbicide treatment using combination of diuron [ $N^{\prime}$-(3,4-dichlorophenyl)$\mathrm{N}, \mathrm{N}$-dimethylurea] and terbacil [5-chloro-3-(1,1-dimethyl)-6-methyl-2,4(1H,3H)-pyrimidinedione] applied at $1.1 \mathrm{~kg}$ a.i./ha of each herbicide to the $3 \mathrm{~m}$ wide strip under the trees. The pre-emergent herbicides were applied prior to treatment with compost mulch. No herbicide was applied in 2000, but all weeds were mechanically cut to ground level in June 2000.

Each orchard was divided in half, across tree rows, and the half to receive compost mulch was selected randomly by a coin flip. Each half of each orchard contained five plots treated with pre-emergent herbicides and five untreated. Each orchard, therefore, had a total of 20 plots, $3 \mathrm{~m} \times 20 \mathrm{~m}$ in size: five with compost and pre-emergent herbicide, five with compost and no pre-emergent herbicide, five with no compost and pre-emergent herbicide, and five with no compost and no pre-emergent herbicide. The compost mulch was a mixture of turkey (Meleagris gallopavo L.) and chicken (Gallus gallus domesticus L.) litter with hardwood chips added to a C:N ratio of 60:1 and a moisture level maintained at $50 \%(\mathrm{w} / \mathrm{w})$. The mixture was turned for aeration each week over a 3-month composting period under a roofed structure at the Potomac Valley Conservation Facility in Moorefield, $\mathrm{WV}$, an experimental poultry mulch producing facility. The compost mulch was applied at a depth of $6 \pm 0.5 \mathrm{~cm}$ (fresh wt. $1.6 \mathrm{~g} / \mathrm{cm}^{2}$, dry wt. $1.1 \mathrm{~g} / \mathrm{cm}^{2}$ ) in a $3 \mathrm{~m}$ wide strip under the apple trees in June 1999. Ten single tree subplots in each orchard (five having received residual herbicide and five without residual herbicide) received compost to a depth of $12 \pm 0.5 \mathrm{~cm}$ (fresh wt. $4.0 \mathrm{~g} / \mathrm{cm}^{2}$, dry wt. $2.9 \mathrm{~g} / \mathrm{cm}^{2}$ ). 


\subsection{Weed management}

The degree of weed control provided by the various treatments was estimated by counts of the percent ground area covered by vegetation in four randomly located $1 \mathrm{~m}^{2}$ subsamples in each of the five replicates per treatment and orchard (20 samples per treatment combination). Percent ground area covered was visually estimated by two individuals in October 1999, May 2000, and September 2000.

\subsection{Disease management}

On 5 June 2000 and 14 June 2001, apple scab was estimated by rating the percentage of leaf area covered with lesions. Nine trees in both compost treated and untreated control plots were sampled in each orchard. On each tree, 10 leaves from the mid-terminal growth and 10 leaves from spur shoots were randomly selected. Disease incidence was rated on a scale 0-4, where 0 was no scab lesion, 1 was $1-25 \%, 2$ was $26-50 \%$, 3 was $51-75 \%$, and 4 was $76-100 \%$ of the leaf surface with scab lesions.

A controlled laboratory trial was conducted to study the effect of composted poultry manure mulch on the growth of $M$. fructicola, used as a model for fruit decay fungi. The experimental unit was a plastic container $(18 \mathrm{~cm} \times 30 \mathrm{~cm})$ with lid. Each treatment was replicated four times and consisted of: (1) clean fruit + sterilized compost, (2) clean fruit + active compost, (3) clean fruit + active compost + infected fruit, (4) clean fruit + sterilized compost + infected fruit. Treatments were designed to determine if $M$. fructicola either developed from incipient infection or grew from an infected fruit over the compost mulch to a clean fruit, and to factor out effects of antimicrobial agents associated with active compost versus the physical structure of the mulch.

On 20 September 1999, 181 of compost from the same source as the field study was collected, following 3 months of field exposure without turning the pile. Half of the compost was sterilized by autoclaving for $47 \mathrm{~min}$ on gravity cycle. The sterile compost was then re-hydrated with deionized water to the same moisture content as the active compost $(\%, w / w)$. Sixteen peaches without symptoms of brown rot were collected from a sprayed orchard. Another 16 peaches with brown rot symptoms were collected from the ground at the base of a peach tree with heavy brown rot infection in an unsprayed orchard. All peaches were surface sterilized with a $0.525 \%$ sodium hypochlorite solution for $3 \mathrm{~min}$ and rinsed with deionized water. For all treatments, a clean peach was placed on the bottom of the plastic container. For treatments 3 and 4 one infected fruit was placed $15 \mathrm{~cm}$ from the clean fruit ensuring that there was no physical contact between them. A layer of mulch consisting of $2000 \mathrm{ml}$ of compost (either active or sterile) ca. $5 \mathrm{~cm}$ deep, was placed evenly around the fruit in each container, such that the fruit were still visible, and the lid was replaced. All containers were held in a growth chamber at $22 \pm 2{ }^{\circ} \mathrm{C}$ and photoperiod 12:12 h L:D. Fungal growth on the clean fruit was estimated on 19 October 1999 and 21 January 2000, using a fungal colonization scale ranging from 0 for no growth, 1 for $1-20 \%$, 2 for $21-40 \%, 3$ for $41-60 \%, 4$ for $61-80 \%$ and 5 for $81-100 \%$ colonization of the fruit.

\subsection{Insect management}

The arthropod community in the apple orchard plots was sampled using pitfall traps. Each trap consisted of a $200 \mathrm{ml}$ glass jar with $50 \mathrm{ml}$ ethylene glycol. The jar was buried in the ground so that the top of the jar was level with the ground or surface of the compost mulch. The jar was covered with a plastic Petri dish suspended over the top for protection. Four pitfall traps were placed under trees in the low depth $(6 \mathrm{~cm})$ compost treated and untreated control plots of each orchard. Two of the four pitfall traps were in subplots that received the residual herbicide treatment and two were in subplots without residual herbicide. The traps were monitored for periods of one week beginning 24 June, 4 August, and 17 September 1999; 26 June and 21 August 2000; 18 June and 9 August 2001. Several traps were lost in June 2001 due to heavy rain and rodent damage leaving only three traps each in the compost treated and untreated control plots covering both orchards. Pretreatment pitfall sampling in 1997 had shown no significant differences in arthropod abundance between orchards (Mathews et al., 2002). Arthropods were identified to family or order.

Leaf mines produced by $P$. blancardella were counted on 5 June 2001. These were mines from offspring of the overwintering generation. Six trees were randomly selected from each of the compost treated 
and untreated plots in each orchard. For each tree, a 5 min count recorded all mines seen while walking around the tree.

Populations of E. lanigerum were destructively sampled in one of the orchards. Trees were pushed over with a bulldozer, exposing the root systems, in October 2001. Ten trees in each of the compost treated and untreated control plots were examined and rated for aphid colonies and presence of root galls produced by E. lanigerum feeding on the roots. A rating of $0-6$, where 0 is no root galls and 6 is the entire root system extensively galled or aphids present was used to evaluate the extent of the aphid infestation.

\subsection{Statistical analysis}

Where data could be transformed to meet the assumptions of normality and homogeneous variances a split plot analysis of variance was done to test for treatment effects (SAS Institute, 1996). Weed cover data were further examined with linear contrasts to test for the effect of compost depth. Data on insect abundances from pitfall trapping were log transformed and treatment effects tested with least significant differences. Data on apple scab incidence were compared using 95\% confidence intervals. Data on brown rot growth in the laboratory could not be normalized and were analyzed by the nonparametric Kruskal-Wallis test (Conover, 1971). Infestation levels of P. blancardella and $E$. lanigerum also could not be normalized and were analyzed with the nonparametric Mann-Whitney test (Conover, 1971).

\section{Results}

\subsection{Weed management}

Following applications of glyphosate, mulch applications improved weed control during 1999 (Table 1), but there was no effect of residual herbicides. In October 1999, average weed abundance was 7 and $10 \%$ ground area covered for plots treated or not treated with residual herbicides. Mulched plots had $2 \%$ or less ground area covered, compared with $25 \%$ in control plots (Table 1). Weed abundance was affected by depth of mulch application in October 1999 and May 2000, when there were fewer weeds in the plots receiving
Table 1

Weed control provided by pre-emergence herbicides and three depths of composted poultry manure in combination with glyphosate applied in June 1999 in two apple orchards in West Virginia, USA, with results from analysis of variance

\begin{tabular}{lcll}
\hline Main effects & \multicolumn{3}{c}{ Percent ground area covered } \\
\cline { 2 - 4 } & October & May & September \\
& 1999 & 2000 & 2000 \\
\hline Herbicide applied & 7 & 25 & 72 \\
Herbicide not applied & 10 & 36 & 73 \\
Mulch depth $0 \mathrm{~cm}$ & 25 & 51 & 81 \\
Mulch depth $6 \mathrm{~cm}$ & 2 & 28 & 69 \\
Mulch depth $12 \mathrm{~cm}$ & 1 & 15 & 68 \\
$P>F$ & & & \\
Orchard & 0.03 & 0.01 & 0.01 \\
Herbicide & 0.32 & 0.01 & 0.91 \\
Mulch & 0.01 & 0.01 & 0.14 \\
Herbicide $\times$ mulch interaction & 0.41 & 0.07 & 0.81 \\
Linear effect of mulch depth & 0.01 & 0.01 & 0.88 \\
\hline
\end{tabular}

$12 \mathrm{~cm}$ mulch (Table 1). During the 2000 growing season perennial weeds grew through the mulch and dominated both orchards. The most prevalent weeds were johnsongrass (Sorghum halepense (L.) Pers.), pokeweed (Phytolacca americana L.), ailanthus (Ailanthus altissima (Miller) Swingle), blackberry (Rubus sp.), and poison ivy (Toxicodendron radicans (L.) Kuntze). By September 2000, neither pre-emergence herbicides nor mulch significantly reduced weed abundance.

The combined application of glyphosate in May and high rate of mulch in June 1999 provided weed control for the longest time, but perennial weeds emerged by September 2000, the end of the second season after application. Mulch had decreased from 6.0 to $4.8 \mathrm{~cm}$, but the dry weight decrease was only $16 \%$, indicating that compost persisted as mulch for at least two growing seasons.

\subsection{Disease management}

There was no difference in apple scab in June 2000 or 2001 as a result of compost treatment. The average incidence in compost treated plots was 1.25 (S.E. = $0.10)$ and 0.29 (S.E. $=0.04)$, in untreated control plots $1.11($ S.E. $=0.14)$ and $0.28($ S.E. $=0.05)$ for 2000 and 2001, respectively.

There was a significant reduction in brown rot growth on previously clean peach fruit in active 
Table 2

Mean $\log$ number $( \pm$ S.E.) of arthropods collected in pitfall traps during 1999

\begin{tabular}{|c|c|c|c|c|c|c|}
\hline \multirow[t]{2}{*}{ Feeding group } & \multicolumn{2}{|l|}{1 July } & \multicolumn{2}{|l|}{11 August } & \multicolumn{2}{|l|}{24 September } \\
\hline & Control & Compost & Control & Compost & Control & Compost \\
\hline All predators & $0.76 \pm 0.20$ & $0.96 \pm 0.20$ & $0.47 \pm 0.14$ & $1.00 \pm 0.14^{\mathrm{a}}$ & $0.63 \pm 0.07$ & $0.91 \pm 0.07^{\mathrm{a}}$ \\
\hline Carabids & $0.11 \pm 0.07$ & $0.27 \pm 0.07$ & $0.10 \pm 0.06$ & $0.00 \pm 0.06$ & $0.17 \pm 0.10$ & $0.29 \pm 0.10$ \\
\hline Staphylinids & $0.16 \pm 0.28$ & $0.61 \pm 0.28^{\mathrm{a}}$ & $0.04 \pm 0.12$ & $0.61 \pm 0.12^{\mathrm{a}}$ & $0.25 \pm 0.16$ & $0.27 \pm 0.16$ \\
\hline Araneae & $0.54 \pm 0.09$ & $0.41 \pm 0.09$ & $0.25 \pm 0.12$ & $0.43 \pm 0.12$ & $0.27 \pm 0.08$ & $0.58 \pm 0.08^{\mathrm{a}}$ \\
\hline Ants & $1.67 \pm 0.24$ & $1.56 \pm 0.24$ & $1.11 \pm 0.19$ & $1.14 \pm 0.19$ & $1.16 \pm 0.18$ & $1.13 \pm 0.18$ \\
\hline Detritivores & $1.62 \pm 0.19$ & $1.19 \pm 0.19$ & $1.45 \pm 0.28$ & $2.49 \pm 0.28^{\mathrm{a}}$ & $1.71 \pm 0.14$ & $2.67 \pm 0.14^{\mathrm{a}}$ \\
\hline All herbivores & $1.92 \pm 0.17$ & $1.76 \pm 0.17$ & $1.72 \pm 0.24$ & $1.84 \pm 0.24$ & $1.63 \pm 0.12$ & $1.47 \pm 0.12$ \\
\hline Aphids & $0.83 \pm 0.17$ & $0.25 \pm 0.17^{\mathrm{a}}$ & $1.27 \pm 0.44$ & $1.40 \pm 0.44$ & $1.04 \pm 0.15$ & $0.65 \pm 0.15$ \\
\hline Total prey & $1.74 \pm 0.19$ & $1.24 \pm 0.19^{\mathrm{a}}$ & $1.75 \pm 0.30$ & $2.60 \pm 0.30^{\mathrm{a}}$ & $1.87 \pm 0.11$ & $2.69 \pm 0.11^{\mathrm{a}}$ \\
\hline
\end{tabular}

Each value represents the mean number collected over 1 week prior to date of collection in eight traps per treatment.

${ }^{\text {a }}$ Difference between compost and control within feeding group and date at $P<0.05$.

compost compared with sterilized compost in the laboratory experiment. After one month the average extent of brown rot growth was 1.50 on peach in active compost and 4.50 in inactive compost $(P<0.05$, Kruskal-Wallis test). After 4 months there was no further increase of brown rot with an average rating of 1.25 in active, 3.60 in inactive compost $(P<0.05$, Kruskal-Wallis test).

\subsection{Insect management}

A summary of the arthropods caught on apple orchard floor is presented in Tables 2 and 3. Staphylinids and carabids responded to the addition of compost with significantly greater abundance in July and August 1999 . Spiders were significantly more abundant in the compost plots than in the untreated control in September 1999 and August 2000. The overall abundance of predators was significantly higher in the compost plots from August to September 1999 (Table 2). Ants showed no response to the application of compost (Tables 2 and 3).

The detritivore population was significantly greater in the compost plots in August and September 1999 and in August 2000 (Table 2). Migrating E. lanigerum nymphs, the predominant species of aphid included in Table 2, were significantly more abundant in the untreated control plots than in the compost plots in July 1999 and June 2000, and total herbivores significantly more abundant in the control plots in June 2000. Overall density of potential prey for the predatory arthropods was significantly higher in the untreated control

Table 3

Mean $\log$ number $( \pm$ S.E. $)$ of arthropods collected in pitfall traps during $2000^{\mathrm{a}}$

\begin{tabular}{lllll}
\hline Feeding group & \multicolumn{2}{l}{ 26 June } & & \multicolumn{2}{l}{ 21 August } \\
\cline { 2 - 3 } & Control & Compost & Control & Compost \\
\hline All predators & $1.49 \pm 0.08$ & $1.68 \pm 0.08$ & $1.18 \pm 0.08$ & $1.40 \pm 0.08$ \\
$\quad$ Carabids & $0.47 \pm 0.13$ & $0.76 \pm 0.13$ & $0.67 \pm 0.07$ & $0.73 \pm 0.07$ \\
$\quad$ Staphylinids & $0.53 \pm 0.26$ & $0.87 \pm 0.26$ & $0.60 \pm 0.14$ & $0.85 \pm 0.14$ \\
$\quad$ Araneae & $0.66 \pm 0.10$ & $0.79 \pm 0.10$ & $0.16 \pm 0.09$ & $0.50 \pm 0.09^{\mathrm{a}}$ \\
Ants & $1.21 \pm 0.13$ & $1.31 \pm 0.13$ & $0.38 \pm 0.12$ & $0.74 \pm 0.12$ \\
Detritivores & $1.30 \pm 0.12$ & $1.51 \pm 0.12$ & $0.87 \pm 0.12$ & $1.19 \pm 0.12^{\mathrm{a}}$ \\
All herbivores & $1.02 \pm 0.19$ & $0.49 \pm 0.19^{\mathrm{a}}$ & $0.80 \pm 0.10$ & $0.77 \pm 0.10$ \\
$\quad$ Aphids & $1.83 \pm 0.16$ & $1.26 \pm 0.16^{\mathrm{a}}$ & $0.21 \pm 0.11$ & $0.31 \pm 0.11$ \\
Total prey & $1.97 \pm 0.13$ & $1.70 \pm 0.13$ & $0.79 \pm 0.15$ & $0.92 \pm 0.15$
\end{tabular}

Each value represents the mean number collected over 1 week prior to date of collection in eight traps per treatment.

${ }^{\text {a }}$ Difference between compost and control within feeding group and date at $P<0.05$. 
Table 4

Herbicide (Herb) by compost interaction terms (log mean) for arthropod pitfall trap data, means within rows followed by the same letter are not significantly different, $P<0.05$, least-squares means separation

\begin{tabular}{|c|c|c|c|c|c|}
\hline \multirow[t]{3}{*}{ Variable } & \multirow[t]{3}{*}{ Date } & \multicolumn{4}{|c|}{ Interaction mean } \\
\hline & & \multicolumn{2}{|c|}{ +Compost } & \multicolumn{2}{|c|}{-Compost } \\
\hline & & + Herb & - Herb & + Herb & - Herb \\
\hline Total herbivores & September 1999 & $1.32 \mathrm{~b}$ & $1.62 \mathrm{a}$ & $1.73 \mathrm{a}$ & $1.54 \mathrm{ab}$ \\
\hline Aphids & September 1999 & $0.58 \mathrm{~b}$ & $0.73 \mathrm{~b}$ & $1.52 \mathrm{a}$ & $0.56 \mathrm{~b}$ \\
\hline Total prey & September 1999 & $2.58 \mathrm{a}$ & $2.80 \mathrm{a}$ & $2.17 \mathrm{~b}$ & $1.56 \mathrm{c}$ \\
\hline Staphylinids & June 2000 & $1.18 \mathrm{a}$ & $0.69 \mathrm{bc}$ & $0.39 \mathrm{c}$ & $0.82 \mathrm{~b}$ \\
\hline Spiders & August 2000 & $0.23 \mathrm{bc}$ & $0.78 \mathrm{a}$ & $0.31 \mathrm{~b}$ & $0.00 \mathrm{c}$ \\
\hline
\end{tabular}

plots in July 1999, but by August and September 1999 prey density was significantly higher in the compost plots (Table 2). Pitfall sampling continued through summer 2001, but no difference between plots was detected in any arthropod group.

The application of residual herbicide had a minor impact on arthropod populations. In August 1999, there were more herbivores in herbicide treated $(1.97 \pm 0.24)$ than in untreated plots $(1.59 \pm 0.24)$. In September 1999, there were fewer ants in the herbicide treated $(0.98 \pm 0.18)$ than in the untreated plots $(1.31 \pm 0.18)$. There were also significant interactions between compost and herbicide treatments (Table 4), plots with both herbicide and compost having fewer herbivores in September 1999 and more staphylinids in June 2000. The compost treatment without herbicide resulted in more spiders in August 2000. The herbicide treated plots without compost resulted in greater abundance of aphids in September 1999, and plots with compost had the highest number of total prey.

The population of $P$. blancardella was low in June 2001, with no significant difference between compost (2.08) and untreated plots (3.75 leaf mines per 5 min count). The infestation of roots by E. lanigerum was not affected by the application of compost. The aphid infestation on roots in the compost plots averaged 5.1 and 4.8 in the untreated control $(P>0.05$, Mann-Whitney test).

\section{Discussion}

This study demonstrated that compost application in apple orchards can beneficially impact pest management on the orchard floor (reduced weed growth, reduced herbivores and increased predatory arthropods). There seemed to be some effect on insects in the tree canopy with fewer $P$. blancardella and $E$. lanigerum. Mulching with compost significantly reduced weed growth for a year after application. Both the 6 and $12 \mathrm{~cm}$ depth mulches significantly deterred weed growth into the beginning of the summer following compost application as reported by Swezey et al. (1998) and Smith et al. (2000) in apple and pecan orchards. The reduction of herbicide use to only spot treating problem areas in the orchard could be a significant step toward increasing the environmental sustainability of orchard production. Reduced expenditures for herbicides could also contribute to offsetting the costs associated with acquiring and applying compost.

This study showed that compost application in a mature apple orchard increases the biodiversity of arthropods inhabiting the orchard floor, as was shown previously in other agricultural systems (Pimentel and Warneke, 1989; Reichert and Bishop, 1990; Badejo et al., 1995; Mathews et al., 2002). Numbers of predators and detritivores were enhanced by the application of compost as in a young apple orchard in West Virginia, USA (Mathews et al., 2002). Increasing arthropod biodiversity alone may make ecosystems more sustainable (Paoletti, 1999; Altieri, 1999).

The increase in predator abundance in compost treated plots may be related to the reduction in herbivore pests documented in this study. The abundance of $P$. blancardella and E. lanigerum were reduced, both spend a portion of their life cycle in or on the soil where they would be exposed to foraging predators. The root sampling indicated that the overall population of E. lanigerum feeding on the roots was not affected 
by compost, whereas the abundance of migrating nymphs was reduced, explaining most of the reduction in herbivores in the pitfall traps. The increase in predator populations is a plausible explanation for the decrease in these pests in the compost treated plots. It has been shown that the physical qualities of mulch can affect migrating E. lanigerum (Damavandian, 1999) which could help explain the reduction in nymphal populations of this insect in the compost plots.

Mathews et al. (2002) showed an increase in codling moth predation rate in compost treated apple orchards. Many other serious pests of apple were also found on the soil for which even small increases in predator activity could have a significant impact in terms of pest management. If reductions in pest populations were sufficient to omit even a single insecticide application, economic and environmental orchard sustainability would be further enhanced.

The herbicide effect on arthropod densities found in this study provided valuable insights for orchard understory management. The increase in herbivores (August 1999) and the reduction in ants (September 1999) are undesirable (Paulson and Akre, 1991; Way and Khoo, 1992), while the reduction of spiders in plots receiving herbicide and no compost (August 2000) could lead to further herbivore increases (Reichert and Bishop, 1990; Bogya and Markó, 1999). Overall, the results indicated that compost was preferable to herbicide application, since beneficial predators were more abundant, herbivores reduced, and weed suppression was greater in mulched plots compared to herbicide treatment for at least the first year after compost application. However, the experimental orchards had not been commercially managed and the net effect of using compost mulch instead of herbicides would need to be evaluated within the context of other horticultural and pest management operations. Cost of compost depends on local availability so the economic sustainability of using compost mulch would have to be determined for each farm.

Inhibition of fungal growth was demonstrated in the laboratory with the brown rot fungus, most likely through competition for resources from the higher microbial biodiversity in the active compost. Windels (1997) indicated that compost application helped control plant disease by reducing inoculum, suppressing disease symptoms, and preventing buildup of inoculum. The present results suggest that com- post may affect fruit rot by reducing the growth of inoculum under trees but incidence of apple scab was not reduced in the compost treated plots. While $V$. inaequalis winters in fallen leaves on the ground, inoculum can be carried by wind from nearby infected trees (MacHardy, 1996) and it was not determined whether primary or secondary inoculum was responsible for the observed scab symptoms. Apple leaves in compost treated orchards have higher nutritional quality (Swezey et al., 1998) and with the ability of $V$. inaequalis to respond to nutritional changes in the host (Keitt and Boone, 1954), more vigorous scab infections may be possible in treated orchards.

\section{Conclusion}

Since compost mulch provided equally favorable weed suppression as herbicide application, and increased numbers of beneficial arthropods in the orchard, its use should be recommended to increase the sustainability of orchard production systems. In addition to the improved pest management demonstrated by this study, enhancement of soil and tree health are widely recognized as benefits of compost use management (Allison, 1973; Glover et al., 2000; Smith et al., 2000). Transportation costs, the potential for phosphorus runoff (Preusch et al., 2002), and the possible increase in rodent injury may prevent widespread adoption of compost as a standard practice, but where it is economically feasible compost application should be encouraged. As Doran (2002) found, the creation of a more biologically diverse ecosystem through compost addition is likely to have greater consequences for sustainability of orchard production.

\section{Acknowledgements}

We thank Clarissa R. Mathews, Patricia Gundrum, Peggy L. Preusch. Henry W. Hogmire, Alan Biggs, and Keith Yoder for their valuable comments on an earlier draft of the manuscript.

\section{References}

Allison, F.E., 1973. Soil Organic Matter and its Role in Crop Production. Elsevier, Amsterdam. 
Altieri, M.A., 1999. The ecological role of biodiversity in agroecosystems. Agric. Ecosyst. Environ. 74, 19-31.

Andrews, P.K., Glover, J.D., Reganold, J.P., 2001. Horticultural performance, soil quality, and orchard profitability of integrated, organic, and conventional apple production systems. In: Proceedings of the Integrated Fruit Production. IOBC/WPRS Bull. 24 (5), 393-400.

Arthur, M.A., Wang, Y., 1999. Soil nutrients and microbial biomass following weed-control treatments in a Christmas tree plantation. Soil Sci. Soc. Am. J. 63, 629-637.

Autio, W.R., Greene, D.W., Cooley, D.R., Schupp, J.R., 1991. Improving the growth of newly planted apple trees. HortScience 26, 840-843.

Badejo, M.A., Tian, G., Brussaard, L., 1995. Effect of various mulches on soil microarthropods under a maize crop. Biol. Fert. Soil. 20, 294-298.

Bogya, S., Markó, V., 1999. Effect of pest management systems on ground-dwelling spider assemblages in an apple orchard in Hungary. Agric. Ecosyst. Environ. 73, 7-18.

Brust, G.E., 1993. Natural enemies in straw-mulch reduce Colorado potato beetle populations and damage in potato. Biol. Contr. 4 , 163-169.

Cogliastro, A., Gagnon, D., Bouchard, A., 1993. Effects of site and silvicultural treatments on growth, biomass allocation and nitrogen nutrition of the seedlings of four broadleaved species on plantations in southwestern Quebec. Can. J. For. Res. 23, 199-209.

Conover, W.J., 1971. Practical Nonparametric Statistics. Wiley, New York, USA.

Culliney, T.W., Pimentel, D., 1985. Ecological effects of organic agricultural practices on insect populations. Agric. Ecosyst. Environ. 15, 253-266.

Damavandian, M.R., 1999. Biology of subterranean populations of woolly apple aphid, Eriosoma lanigerum (Hausmann) (Homoptera: Aphididae), in apple orchards. Ph.D. Thesis. Department of Entomology and Nematology, University of Stellenbosch, South Africa.

Doran, J.W., 2002. Soil health and global sustainability: translating science into practice. Agric. Ecosyst. Environ. 88, 119-127.

Glover, J.D., Reganold, J.P., Andrews, P.K., 2000. Systematic methods for rating soil quality of conventional, organic, and integrated apple orchards in Washington State. Agric. Ecosyst. Environ. 80, 29-45.

Hoitink, A.J., Boehm, M.J., 1999. Biocontrol within the context of soil microbial communities: a substrate-dependent phenomenon. Annu. Rev. Phytopathol. 37, 427-446.

Keitt, G.W., Boone, D.M., 1954. Induction and inheritance of mutant characters in Venturia inaequalis in relation to its pathogenicity. Phytopathology 44, 362-370.

Kennedy, A.C., 1999. Bacterial diversity in agroecosystems. Agric. Ecosyst. Environ. 74, 65-76.

Lu, Y.C., Watkins, B., Teasdale, J., 1999. Economic analysis of sustainable agricultural cropping systems for mid-Atlantic states. J. Sustain. Agric. 15, 77-93.

MacHardy, W.E., 1996. Apple Scab: Biology, Epidemiology, and Management. APS Press, St. Paul, MN, USA.
Mathews, C.R., Bottrell, D.G., Brown, M.W., 2002. A comparison of conventional and alternative understory management practices for apple production: multi-trophic effects. J. Appl. Soil Ecol. 21, 221-231.

Morris, H.M., 1922. The insect and other invertebrate fauna of arable land at Rothamsted. Ann. Appl. Biol. 9, 282-305.

Niggli, U., Weibel, F.P., Gut, W., 1990. Weed control with organic mulch materials in orchards. Results from 8 year field experiments. Acta Hort. 285, 97-102.

Paoletti, M.G., 1999. Using bioindicators based on biodiversity to assess landscape sustainability. Agric. Ecosyst. Environ. 74, $1-18$.

Paulson, G.S., Akre, R.D., 1991. Role of predaceous ants in pear psylla (Homoptera: Psyllidae) management: estimating colony size and foraging range of Formica neoclara (Hymenoptera: Formicidae) through a mark-recapture technique. J. Econ. Entomol. 84, 1437-1440.

Pimentel, D., Warneke, A., 1989. Ecological effects of manure, sewage sludge and other organic wastes on arthropod populations. In: Russell, G.E. (Ed.), Biology and Population Dynamics of Invertebrate Crop Pests. Intercept, Andover, pp. 275-304.

Pinamonti, F., 1998. Compost mulch effects on soil fertility, nutritional status and performance of grapevine. Nutr. Cycl. Agroecosyst. 51, 239-248.

Preusch, P.L., Adler, P.R., Sikora, L.J., Tworkoski, T.J., 2002. Nitrogen mineralization rates and phosphorus availability in composted and uncomposted poultry litter. J. Environ. Qual. 31, 2051-2057.

Reganold, J.P., Glover, J.D., Andrews, P.K., Hinman, H.R., 2001. Sustainability of three apple production systems. Nature 410 , 926-930.

Reichert, S.E., Bishop, L., 1990. Prey control by an assemblage of generalist predators: spiders in garden test systems. Ecology 71 (4), 95-119.

SAS Institute, 1996. SAS/STAT User's Guide, Release 6.03e. SAS Institute, Cary, NC.

Settle, W.H., Ariawan, H., Astuti, E.T., Cahyana, W., Hakim, A.L., Hindayana, D., Lestari, A.S., Sartanto, P., 1996. Managing tropical rice pests through conservation of generalist natural enemies and alternative prey. Ecology 77, 19751988.

Smith, M.W., Carroll, B.L., Cheary, B.S., 2000. Mulch improves pecan tree growth during orchard establishment. HortScience 35, 192-195.

Swezey, S.L., Werner, M.R., Buchanan, M., Allison, J., 1998. Comparison of conventional and organic apple production systems during three years of conversion to organic management in coastal California. Am. J. Atlantic Agric. 13, 162-180.

Way, M.J., Khoo, K.C., 1992. Role of ants in pest management. Annu. Rev. Entomol. 37, 479-503.

Windels, C.E., 1997. Altering community balance: organic amendments, selection pressures, and biocontrol. In: Andow, D.A., Ragsdale, D.W., Nyvall, R.F. (Eds.), Ecological Interactions and Biological Control. Westview Press, Boulder, $\mathrm{CO}$ 